\title{
Calcium renal lithiasis: metabolic diagnosis and medical treatment
}

\author{
Litiase renal cálcica: diagnóstico metabólico e tratamento médico
}

\author{
Miguel Angel Arrabal-Polo', Miguel Arrabal-Martin", Juan Garrido-Gomez"II \\ San Cecilio University Hospital, Granada, Spain
}

'MD. Resident in training, Urology Department, San Cecilio University Hospital, Granada, Spain. "MD, PhD. Attending Physician, Urology Department, San Cecilio University Hospital, Granada, Spain.

'"MD, PhD. Attending Physician, Traumatology Department, San Cecilio University Hospital,

Granada, Spain.

\section{KEY WORDS: \\ Kidney calculi. \\ Therapeutics. \\ Metabolism. \\ Diagnosis. \\ Pharmacy. \\ Calcium.}

\section{PALAVRAS-CHAVE:}

Cálculos renais.

Terapêutica.

Metabolismo.

Diagnóstico.

Farmácia.

Cálcio.

\begin{abstract}
Calcium renal lithiasis is a frequent condition that affects the worldwide population and has a high recurrence rate. Different metabolic changes may trigger the onset of calcium stone disorders, such as hypercalciuria, hyperoxaluria, hyperuricosuria, hypocitraturia and others. There are also other very prevalent disorders that are associated with calcium calculi, such as arterial hypertension, obesity and loss of bone mineral density. A correct diagnosis needs to be obtained through examining the serum and urinary parameters of mineral metabolism in order to carry out adequate prevention and treatment of this condition. Once the metabolic diagnosis is known, it is possible to establish dietary and pharmacological treatment that may enable monitoring of the disease and prevent recurrence of stone formation. Some advances in treating this pathological condition have been made, and these include use of sodium alendronate in patients with calcium renal lithiasis and osteopenia/osteoporosis, or use of a combination of a thiazide with a bisphosphonate. In summary, calcium renal lithiasis often requires multidrug treatment with strict control and follow-up of patients.
\end{abstract}

\section{RESUMO}

Litíase renal cálcica é uma doença comum que afeta a população no mundo todo e tem alta taxa de recorrência. Diferentes alterações metabólicas podem desencadear o aparecimento de distúrbios de pedras de cálcio, como hipercalciúria, hiperoxalúria, hiperuricosúria, hipocitratúria e outros. Existem também doenças altamente prevalentes associadas à doença de cálculo de cálcio, como hipertensão, obesidade e perda de densidade óssea mineral. Para realizar prevenção e tratamento adequados, é necessário diagnóstico correto, examinando o metabolismo mineral sérico e urinário. Depois de conhecer o diagnóstico metabólico, é possível estabelecer um tratamento dietético e farmacológico que permita controlar a doença e prevenir a recorrência de cálculos biliares. Há alguns avanços no tratamento dessa doença e incluem o uso de alendronato de sódio em pacientes com nefrolitíase de cálcio e osteopenia/osteoporose, ou a combinação de um tiazídico com um bifosfonato. Em resumo, litíase renal cálcica exige, muitas vezes, um tratamento multidroga com rigorosos controle e acompanhamento de pacientes. 


\section{INTRODUCTION}

Calcium kidney stones are an important urological and nephrological pathological condition that affects a high percentage of the population during life. The information available on their etiology, clinical presentation, diagnosis and treatment (medical and non-medical) is very extensive and therefore, in this review article, we will address their metabolic diagnosis and medical treatment, particularly by reviewing published papers in the most important databases.

PubMed, Lilacs, Embase and Cochrane Library were searched for systematic reviews and practice guidelines, using the MeSH terms Kidney calculi AND Calcium AND Metabolism with the following limits: review, clinical trial, randomized clinical trial, diagnostic tests and evaluation studies. We found a total of 533 articles in PubMed, 43 articles in Embase, 26 articles in Cochrane and 6 in Lilacs. Finally, we selected a total of 63 articles from PubMed, 6 from Cochrane and 3 from Embase. The 6 articles and 3 articles from Cochrane and Embase were also among the 63 articles used from PubMed (Table 1).

\section{EPIDEMIOLOGY}

Renal lithiasis is a very frequent pathological condition among the worldwide population, with varying incidence according to distinct geographical regions. Calcium-based stones, both in oxalate and in phosphate form, prevail in developed countries, while infectious lithiasis remains the main cause of this condition in developing countries. ${ }^{1}$ Renal lithiasis occurs at least once in life in $15 \%$ of Caucasian men and in $6 \%$ of women, with recurrence of around $50 \% .^{2}$
In most cases (around 75\%), stones have a calcium composition, and they generally present in the form of calcium oxalate, whereas other types of lithiasis are less frequent. ${ }^{2}$ Increased frequency of calcium phosphate stones has been observed over the last few decades, and above all among women, with metabolic and bone-derived diseases. ${ }^{3}$

The geographical variability in the prevalence of lithiasis is also noteworthy, since in some zones it is very high, while in others it is nonexistent. ${ }^{4}$ In general, urinary lithiasis has a mean incidence of $0.5-1 \%$, and an annual prevalence of $4-5 \% .^{5}$

\section{CLINICAL AND METABOLIC DIAGNOSIS}

\section{Clinical diagnosis}

Renal colic is the most common clinical presentation of calcium renal lithiasis and leads to a high admission rate in the emergency rooms of hospitals. It is very important to objectively describe the type of pain, quantify it, determine the origin of irradiation and collect any personal and family histories relating to calcium renal lithiasis. Patients should be asked about their dietary patterns, fluid intake, use of medication and type of physical activity that they perform. ${ }^{6}$ Simple abdominal radiography and ultrasonography are the imaging techniques usually ordered at the beginning of the study, although abdominal computed tomography (CT) is the gold standard imaging technique (Table 2) for diagnosing and classifying renal lithiasis. Today, and thanks to new imaging techniques such as dual-energy computed tomography, it is possible to obtain a sufficiently accurate diagnosis to be able to differentiate calcium stones from uric acid, or from other types with less frequent chemical compositions. ${ }^{7}$

Table 1. Search performed using the terms "Calcium stones AND Metabolism" in the principal databases, and numbers of articles selected

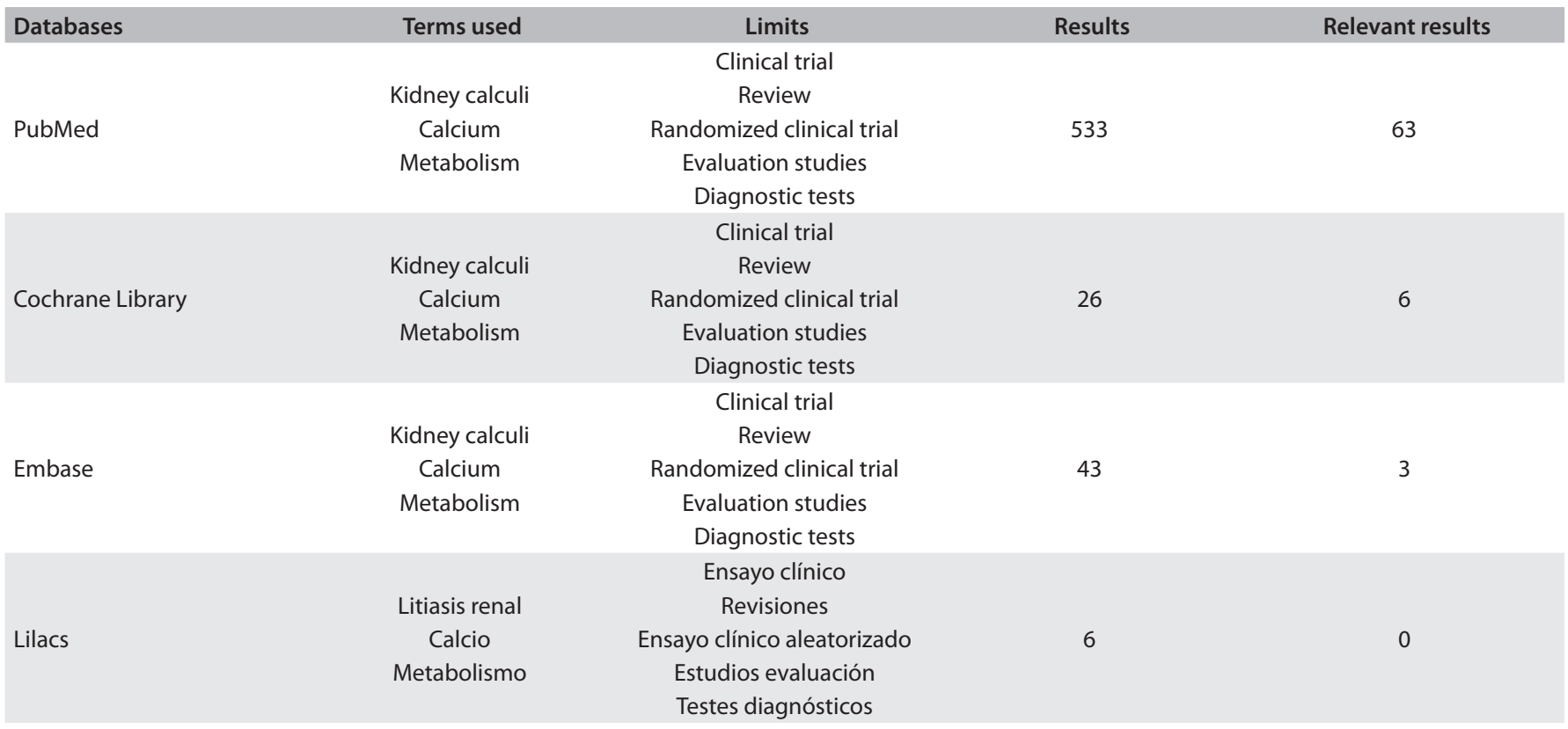


Table 2. Summary of highlights of each of the sections covered in the review along with their level of scientific evidence; main results and strategies evaluated in the review.

Level of evidence

\section{Clinical and metabolic diagnosis}

CT scan is the "gold standard" for diagnosing calcium stones

Randall's plaque is important in development and pathogenesis of calcium oxalate stones

Stone composition is well described with infrared spectroscopy and X-ray diffraction

24-hour urine test is recommendable for diagnosing metabolic alterations in calcium stones

Hypercalciuria is the most frequent alteration in metabolic studies

Calcium lithiasis and its relationship with other prevalent diseases

Arterial hypertension and obesity are related to calcium stones

Bone mineral density loss and calcium stones are two pathological conditions correlated with genetics and calcium and phosphorus metabolism

\section{Medical management and prophylaxis of calcium lithiasis}

Fluid intake of more than 2 liters/day is recommended

\section{$1 \mathrm{~b}$}

Calcium intake should be normal (approximately $1000 \mathrm{mg} /$ day)

$1 \mathrm{~b}$

Restriction of oxalate, animal protein, salt and purine intake is recommended

\section{Prevention and pharmacological treatment}

Potassium citrate prevents calcium stones in patients with hypocitraturia and acid $\mathrm{pH}$

Allopurinol is indicated for calcium stones with hyperuricosuria and increased serum uric acid

Thiazides have been demonstrated to decrease calciuria and prevent new episodes of calcium stones

$1 \mathrm{a}$

Bisphosphonates form a new therapy for patients with calcium stones and bone mineral density loss that improves both of these conditions

\section{Metabolic diagnosis}

Lithiasis composed of calcium oxalate is the most frequent type, followed by calcium phosphate. Numerous studies have highlighted the significance that Randall's plaque has in relation to development and pathogenesis of calcium oxalate lithiasis (Table 2), thanks to the use of intraoperative biopsies. ${ }^{8,9}$ It has even been possible to demonstrate that the singularity of the renal papilla depends on the type of renal calcium stone former, i.e. whether it is oxalate or phosphate. ${ }^{10}$ Microscopic lesions on the renal papilla are the main cause of formation of monohydrate calcium oxalate stones, while the location of such lesions and their characteristics will in many instances determine the final morphology of the renal calculus. ${ }^{11}$ Even the presence of lesions in kidney tubular cells may favor aggregation and growth of crystals, which eventually leads to formation of calcium stones. ${ }^{12}$

Calcium stone formation is a complex process that involves numerous metabolic, anatomical and physiopathological mechanisms. Occurrences of supersaturated states of crystallization with the capacity to precipitate in urine are a key factor in calculus formation. The saturation state of a substance is expressed as the ratio between a given substance and its solubility variable. The supersaturated state of the calcium oxalate is unrelated to the urinary $\mathrm{pH}$; however, calcium phosphate saturation increases significantly when the urinary $\mathrm{pH}$ changes from 6 to $7 .^{13,14}$
Metabolic disorders are, beyond any doubt, key factors in the formation and persistence of calcium lithiasis. It is therefore advisable to conduct a complete metabolic study on patients with histories of calcium lithiasis, multiple calcium lithiasis or hardto-treat calcium lithiasis; and on calcium lithiasis-forming children, single kidney patients and occurrences of intestinal disorders, bone disorders or nephrocalcinosis. ${ }^{15}$ Metabolic studies include analysis on the calculi, since each occurrence of lithiasis comprises in itself a certain clinical form of lithiasis disease. Firstly, the macroscopic structure of the calculi, before and after fragmentation, should be examined in order to identify their exact composition through infrared spectroscopy and X-ray diffraction along with other electronic scanning microscopy techniques. On the other hand, chemical analysis of calculi is an inexact method that has now become obsolete. ${ }^{16}$

Regarding blood and urine results, tests should be ordered when it is necessary to know the blood levels of calcium, phosphorus, sodium, potassium, chlorine, magnesium, urea, creatinine and uric acid. In 24-hour urine tests, it is recommendable to determine the urea, creatinine, uric acid, oxalate, citrate and magnesium levels, and to establish the diuresis volume, $\mathrm{pH}$ and urinary density. A fasting urine test to assess the levels of calcium, creatinine, oxalate and citrate is also recommendable. ${ }^{5,7-19}$ The analysis should be extended in order to determine the levels of 
bone resorption markers in cases of nephrocalcinosis, suspected hyperparathyroidism, fasting hypercalciuria or previous treatment for loss of bone mineral density. Blood tests should detect markers for intact parathyroid hormone (iPTH), vitamin D, alkaline phosphatase, osteocalcin and beta-crosslaps. Furthermore, any metabolic study conducted on patients with recurrent calcium renal lithiasis and altered bone remodeling markers can be complemented by performing bone densitometry to objectively assess bone mineral density. ${ }^{20}$

Metabolic studies reveal a series of alterations that can affect the calcium stone composition, and which can be summarized as follows:

\section{Hypercalciuria}

Hypercalciuria is, for many reasons, the most important metabolic risk factor for formation of calcium lithiasis. Hypercalciuria is the most frequently detected metabolic abnormality, in 35-65\% of patients with stones; the relation between urinary calcium levels and occurrences of Randall's plaques is another factor; ${ }^{19,21}$ also, a genetic and molecular relationship with the presence of calcium in urine could be regarded as a further factor. ${ }^{22,23}$ Hypercalciuria is defined, according to different studies, as excretion in urine of more than $260 \mathrm{mg}$ of calcium in 24 hours (or $4 \mathrm{mg}$ of calcium per $\mathrm{kg} /$ day). In clinical practice, it is also valuable to regard hypercalciuria as excretion of more than $250 \mathrm{mg}$ /day in women and $300 \mathrm{mg} /$ day in men. ${ }^{5,9,24}$ Although the term idiopathic hypercalciuria has been used for years to refer to increased urinary calcium levels, it is more accurate to talk about distinct types of hypercalciuria, on the basis that the calcium transport defect may be localized in the gastrointestinal tract, bones or kidneys. Thus, hypercalciuria can be classified into three groups: absorptive hypercalciuria; excretory, or renal, hypercalciuria; and reabsorptive hypercalciuria. ${ }^{5,19-25}$

- Absorptive hypercalciuria: Three types of hypercalciuria have been defined and are characterized by having a calcium/creatinine ratio in urine of less than 0.11 during fasting, and less than 0.22 when there is an overload of calcium in the diet. They differ from each other in that type 1 has high calcium excretion in urine even with a restricted calcium diet; in type 2 , lower calcium levels in urine are detected following restriction of calcium in the diet; and a deficit of serum phosphate is detected in type $3 .^{26,27}$

- Excretory hypercalciuria: This occurs as a result of failure of renal tubular reabsorption of calcium. These patients have calcium/creatinine ratios greater than 0.11 while fasting, and higher than 0.22 after calcium intake. Furthermore, iPTH is found to be within the normal range. ${ }^{19}$

- Reabsorptive hypercalciuria: This results from increased bone resorption, basically in relation to primary hyperparathyroidism. Calcium/creatinine ratios are found to be high while fasting and after calcium overloads greater than 0.11 and 0.22 , respectively, as well as the iPTH levels.

\section{Hyperoxaluria}

Hyperoxaluria is defined as urinary excretion of oxalate higher than $40 \mathrm{mg} /$ day. Increased oxalate excretion in urine seems to be associated with formation of monohydrate calcium oxalate stones, which is a metabolic risk factor in this type of lithiasis disorder. As with hypercalciuria, various types of hyperoxaluria can be distinguished. Primary hyperoxaluria (type 1 and type 2) can be found in patients with enzyme deficits resulting from mutations of a variety of genes, and it involves anomalous and incomplete degradation of oxalates that accumulate in urine before their excretion. However, this condition is usually infrequent. ${ }^{28}$

Enteric hyperoxaluria is the most frequent disorder, and results from malabsorption of fats. Since these fats cannot be absorbed, they bind to calcium and diminish the formation of intestinal calcium-oxalate complexes, and thus increase the intestinal absorption of oxalates. Dietetic hyperoxaluria is caused by an increase in the intake of oxalate-rich food, or excessive intake of vitamin C. ${ }^{29}$

Moreover, the bacterium Oxalobacter formigenes has recently been described as the causative agent of oxalate absorption at intestinal level. It seems that low levels of this microorganism lead to increased oxalate levels, since oxalate metabolism diminishes because of this bacterium. ${ }^{30}$

In the past, bariatric surgery played a significant role in the formation of oxalate calculi, since jejunum-ileum shunts would lead to high levels of hyperoxaluria through increased abdominal absorption of oxalates. This has now been replaced by other techniques with fewer side effects on metabolism. ${ }^{31}$

\section{Hypocitraturia}

Urinary citrate is a recognized inhibitor of oxalate and calcium phosphate stones, through avoiding the formation of the nucleus of stone, its growth and its aggregation. ${ }^{32-34}$ Hypocitraturia can be defined as urinary excretion of citrate less than $320 \mathrm{mg} /$ day. Citrate has a triple protective effect, since it can bind to calcium to prevent formation of complexes, alkalinize urine and have a direct inhibitory effect. Urinary citrate is reabsorbed under states of acidosis, with the result that its urinary excretion decreases. In addition, hypocitraturia has been correlated with chronic diarrhea, extenuating physical exercise and excessive intake of animal proteins. ${ }^{19,35}$

\section{Hyperuricosuria}

Hyperuricosuria is defined as urinary excretion of more than $600 \mathrm{mg} /$ day of uric acid. Excessive presence of this ion in the urine increases heterogeneous nucleation with oxalate calculi, and therefore it plays an influential role in formation of 
oxalate-calcium calculi. In general, increased urinary excretion of uric acid results from high intake of purines, although it can also be associated with other pathological conditions, such as gout, myeloproliferative diseases, myeloma etc. ${ }^{5,36,37}$

\section{Hypomagnesuria}

The disorder of hypomagnesuria is an infrequent cause of formation of calcium oxalate stones. It can be detected in around $1 \%$ of patients and is associated with intestinal inflammatory disease. ${ }^{5,36}$

\section{CALCIUM LITHIASIS AND ITS RELATIONSHIP WITH OTHER PREVALENT DISEASES}

\section{Arterial hypertension and calcium lithiasis}

Numerous studies have analyzed the relationship between lithiasis and arterial hypertension. ${ }^{38,39}$ It seems that increases in circulatory volume and arterial pressure lead to decreased sodium reabsorption at the level of the proximal tubules, which results in diminished calcium reabsorption and subsequently, increased calciuria (Table 2). High sodium intake in these patients' diet is another factor to bear in mind, since this increases the urinary excretion of calcium..$^{40,41}$

\section{Obesity and calcium lithiasis}

A variety of studies in the literature have shown that there is a relationship between body mass index and kidney stones. It has been increasingly recognized that obesity is associated with uric acid-derived lithiasis, although the prevalence of calcium lithiasis can also be high in these patients as a result of the process of hyperuricosuria, which is, as noted earlier, a metabolic risk factor for calcium lithiasis. ${ }^{42}$ It has been observed that obese patients who underwent bariatric surgery have higher levels of oxaluria, which may result in higher incidence of calcium lithiasis. ${ }^{43}$

\section{Loss of bone mineral density and calcium lithiasis}

The involvement of the kidneys in regulating phosphorus-calcium metabolism through excretion and reabsorption of calcium and phosphorus, and in mediating $1.25 \mathrm{OH}$ vitamin $\mathrm{D}$ and iPTH, is well known. It has been shown that the incidence of calcium renal lithiasis is higher in patients with losses of bone mineral density, while calciuria levels are also found to be high. ${ }^{44}$ Some patients present genetic predisposition towards both calcium renal lithiasis and loss of bone mineral density. ${ }^{45}$ Higher incidence of pathological fractures is also seen in osteoporosis patients with calcium renal lithiasis. ${ }^{46,47}$ With regard to clinical data, our group recently found that patients with recurrent calcium renal lithiasis have higher levels of bone remodeling markers, caused by greater loss of bone mass (revealed though bone densitometry) and by higher levels of calciuria in 24-hour tests. ${ }^{20}$ It is worth bearing in mind the relationship between calcium renal lithiasis and osteopenia/osteoporosis (Table 2), especially in patients with recurrent hypercalciuria and elevated bone marker levels, given that these patients could benefit from treatments aimed at improving bone mineral density and reducing the recurrence of stone formation. ${ }^{47-50}$

\section{Diabetes mellitus and calcium lithiasis}

So far, there is no clear evidence of higher prevalence of calcium lithiasis in patients with diabetes mellitus. Only higher incidence of uric acid lithiasis has been detected in these patients, along with increased urinary excretion of uric acid. ${ }^{51,52}$

\section{MEDICAL MANAGEMENT AND PROPHYLAXIS OF CALCIUM LITHIASIS}

Diet

Fluid intake

In general, fluid intake of more than two liters per day is recommended for all patients, since this decreases saturation states by making urine more diluted and lowering the concentrations of crystallizable substances. Low-mineral water, especially with low sodium and calcium levels, is recommended for consumption. ${ }^{53}$

\section{Calcium intake in the diet}

Some years ago, a calcium-restricted diet was recommended, especially among patients presenting both calcium lithiasis and hypercalciuria. However, it has been noticed that restrictedcalcium diets result in higher absorption of enteric oxalate and increased loss of bone mineral density, thereby leading to osteopenia/osteoporosis. A calcium-restricted diet is only recommendable for patients without any risk of loss of bone mineral density or of type 2 absorptive hypercalciuria. For other patients, a normal intake of $1000 \mathrm{mg}$ of calcium per day is recommended in order to prevent both bone demineralization and increased intestinal absorption of oxalate. ${ }^{54,55}$

\section{Fiber-rich food}

Fiber intake leads to a change in bowel transit that diminishes the absorption of both calcium and oxalate and thus reduces the incidence of calcium lithiasis. Therefore, moderate fiber intake is recommended for patients with recurrent lithiasis. However, there is not enough scientific evidence to corroborate the benefits of this measure. ${ }^{53,55}$

\section{Oxalate restriction}

Restriction of the intake of oxalate-rich food is recommended for patients with hyperoxaluria levels greater than $0.45 \mathrm{mmol} / 24 \mathrm{~h}$, as a way of diminishing oxalate absorption in the bowel. This restriction includes rhubarb, chocolate, spinach, walnuts, black tea, etc. ${ }^{53}$ Moderate consumption of vitamin $\mathrm{C}$ is also recommendable, since this leads to natural conversion of ascorbate to 
oxalate, which increases the levels of this substance, and hence those of oxaluria. ${ }^{55}$

\section{Restriction of protein intake}

It is advisable to avoid high protein intake, since this raises calciuria and oxaluria levels. This is therefore harmful for patients with recurrent calcium lithiasis. High protein intake also diminishes urinary citrate levels and lowers urinary $\mathrm{pH} .{ }^{53-57}$

\section{Restriction of salt and purine-rich food}

In general, it is advisable to restrict the intake of salt and purinerich foods among patients with hypercalciuria, or in cases of supersaturation of urinary calcium, since this it increases natriuresis and consequently, calciuria. ${ }^{55}$ Intake of purine-rich foodstuffs (oily fish, meat offal etc.) should also be restricted, since they increase uricosuria, which may be damaging for patients with calcium oxalate lithiasis and hyperuricosuria, as it favors heterogeneous crystallization. ${ }^{55,57}$

\section{PREVENTION AND PHARMACOLOGICAL TREATMENT Potassium citrate}

Administration of potassium citrate increases both urinary $\mathrm{pH}$ and citrate levels in urine. Citrate is a crystallization inhibitor in urine, and it reduces supersaturation of both oxalate and calcium phosphate by inhibiting the aggregation and growth of such crystals (Table 2). It is especially recommended for patients with calcium lithiasis accompanied by hypocitraturia or hyperuricosuria in acid $\mathrm{pH}$. Urinary $\mathrm{pH}$ should be monitored to avoid excessive alkalinization. ${ }^{53,57,58}$

\section{Allopurinol}

Administration of allopurinol is recommended in cases of calcium oxalate lithiasis (Table 2), since it reduces production of endogenous uric acid and hence the presence of uric acid in urine. ${ }^{53}$

\section{Phosphate}

Phosphate administration is indicated for patients with calcium lithiasis and type 3 absorptive hypercalciuria. In such patients, a phosphate deficit may lead to increased calcium levels in urine. ${ }^{27}$

\section{Pyridoxine}

Although there is no clear evidence of beneficial effects from pyridoxine supplementation, this is indicated for patients with calcium oxalate lithiasis and hyperoxaluria. ${ }^{5}$

\section{Thiazides}

Thiazides (hydrochlorothiazide and indapamide, among others) produce an increase in tubular reabsorption of calcium, which diminishes calciuria. ${ }^{53}$ This drug is indicated for the majority of patients with recurrent calcium lithiasis and hypercalciuria (Table 2), since it has been reported to diminish the recurrence of lithiasis and improve the monitoring of this condition. ${ }^{59}$ It has also been noticed that use of thiazides in cases of residual lithiasis resulting from instrumental management of the disorder stabilizes it and prevents further calculus formation. ${ }^{60}$ Thiazides can currently be regarded as an efficient treatment for preventing recurrent lithiasis, and for treating residual lithiasis processes that cannot receive instrumental management. $53,57,59,60$

\section{Bisphosphonate}

Treatment of calcium renal lithiasis with bisphosphonate is novel but, despite the sparseness of studies on its indication, fasting and 24-hour tests have reported decreases in calciuria among patients with calcium renal lithiasis and loss of bone mineral density, following this treatment. ${ }^{61,62}$ Furthermore, some studies have reported that treatment based on sodium alendronate, alone ${ }^{50}$ or in combination with indapamide, ${ }^{63}$ provides improvements for conditions of recurrent lithiasis and loss of bone mineral density (Table 2).

\section{REFERENCES}

1. Alapont Pérez FM, Gálvez Calderón J, Varea Herrero J, et al. Epidemiología de la litiasis urinaria [Epidemiology of urinary lithiasis]. Actas Urol Esp. 2001;25(5):341-9.

2. Bihl G, Meyers A. Recurrent renal stone disease-advances in pathogenesis and clinical management. Lancet. 2001;358(9282):651-6.

3. Evan AP. Physiopathology and etiology of stone formation in the kidney and the urinary tract. Pediatr Nephrol. 2010;25(5):831-41

4. Soucie JM, Coates RJ, McClellan W, Austin H, Thun M. Relation between geographic variability in kidney stones prevalence and risk factors for stones. Am J Epidemiol. 1996;143(5):487-95.

5. Arrabal Martín M, Fernández Rodríguez A, Arrabal Polo MA, Ruíz García MJ, Zuluaga Gómez A. Estudio de factores físico-químicos en pacientes con litiasis renal. [Study of the physical-chemical factors in patients with renal lithiasis]. Arch Esp Urol. 2006;59(6):583-94.

6. Hermida Pérez JA, Pérez Palmes MP, Loro Ferrer JF, Ochoa Urdangarain O, Buduen Nuñez A. Cólico nefrítico en el servicio de urgencias. Estudio epidemiológico, diagnostico y etiopatogénico [Renal colic at emergency departments: Epidemiologic, diagnostic andetiopathogenic study]. Arch Esp Urol. 2010;63(3):173-87.

7. Eliahou R, Hidas G, Duvdevani M, Sosna J. Determination of renal stone composition with dual-energy computed tomography: an emerging application. Semin Ultrasound CT MR. 2010;31(4):315-20.

8. Evan A, Lingeman J, Coe FL, Worcester E. Randall's plaque: pathogenesis and role in calcium oxalate nephrolithiasis. Kidney Int. 2006;69(8):1313-8.

9. Evan AP, Lingeman JE, Coe FL, Worcester EM. Role of interstitial apatite plaque in the pathogenesis of the common calcium oxalate stone. Semin Nephrol. 2008;28(2):111-9. 
10. Matlaga BR, Coe FL, Evan AP, Lingeman JE. The role of Randall's plaques in the pathogenesis of calcium stones. J Urol. 2007;177(1):31-8.

11. Grases F, Costa-Bauzá A, Gomila I, Conte A. Origin and types of calcium oxalate monohydrate papillary renal calculi. Urology. 2010;76(6):1339-45.

12. Tsujihata M. Mechanism of calcium oxalate renal stone formation and renal tubular cell injury. Int J Urol. 2008;15(2):115-20.

13. Worcester EM, Coe FL. Clinical practice. Calcium kidney stones. N Engl J Med. 2010;363(10):954-63.

14. Lancina Martín JA. Litiasis urinaria. Presente y future. Actas Urológicas Españolas. 2005;29(4):339-44. Available from: http://www.elsevier.es/ es/revistas/actas-urologicas-españolas-292/litiasis-urinaria-presentefuturo-13144104-editoriales-2005. Accessed in 2012 (Aug 16).

15. Chandhoke PJ. Evaluación del formador recurrente de cálculos. Urol Clin N Am. 2007;34:315-22. Available from: http://www.elsevier.es/ sites/default/files/elsevier/pdf/507/507v34n03a13122979pdf001. pdf. Accessed in 2012 (Aug 16).

16. Areses Trapote R, Urbieta Garagorri MA, Ubetagoyena Arrieta M, Mingo Monge T, Arruebarrena Lizarraga D. Evaluación de la enfermedad renal litiásica. Estudio metabólico [Evaluation of renal stone disease: metabolic study]. An Pediatr (Barc). 2004;61 (5):418-27.

17. Parmar MS. Kidney stones. BMJ. 2004;328(7453):1420-4.

18. SakhaeeK. Recent advances in the pathophysiology of nephrolithiasis. Kidney Int. 2009;75(6):585-95.

19. Park S, Pearle MS. Fisiopatología y tratamiento de los cálculos de calico. Urol Clin N Am. 2007;34:323-34. Available from: http://www. elsevier.es/sites/default/files/elsevier/pdf/507/507v34n03a13122980 pdf001.pdf. Accessed in 2012 (Aug 16).

20. Arrabal-Polo MA, Arrabal-Martin M, de Haro-Munoz T, et al. Mineral density and bone remodelling markers in patients with calcium lithiasis. BJU Int. 2011;108(11):1903-8; discussion 1908.

21. Yuen JW, Gohel MD, Poon NW, et al. The initial and subsequent inflammatory events during calcium oxalate lithiasis. Clin Chim Acta. 2010;411(15-16):1018-26.

22. Frick KK, Bushisnky DA. Molecular mechanisms of primary hypercalciuria. J Am Soc Nephrol. 2003;14(4):1082-95.

23. Stechman MJ, Loh NY, Thakker RV. Genetic causes of hypercalciuric nephrolithiasis. Pediatr Nephrol. 2009;24(12):2321-32.

24. Worcester EM, Coe FL. New insights into the pathogenesis of idiopathic hypercalciuria. Semin Nephrol. 2008;28(2):120-32.

25. Ossandón Salas E, Storme Cabrera O, Ledesma R, et al. Resultados del estudio metabólico en 54 pacientes con urolitiasis de alto riesgo de recurrencia [Metabolic study results of 54 patients with high risk of recurrent urolithiasis]. Actas Urol Esp. 2009;33(4):429-32.

26. Pak CY, Britton F, Peterson R, et al. Ambulatory evaluation of nephrolithiasis. Classification, clinical presentation and diagnostic criteria. Am J Med. 1980;69(1):19-30.

27. Reina Ruiz CM, Conde Sánchez JM, Domínguez Domínguez $M$ Espinosa Olmedo J, García Pérez M. Papel del fosfato en la litiasis cálcica recidivante. Una visión actual [Role of phosphate in recurrent calcium lithiasis: The recurrent concept]. Arch Esp Urol. 2001;54:102935. Available from: http://pesquisa.bvsalud.org/regional/resources/ ibc-27478. Accessed in 2012 (Aug 16).

28. Hoppe B, Beck BB, Milliner DS. The primary hyperoxalurias. Kidney Int. 2009;75(12):1264-71.

29. Hoppe B, Langman CB. A United States survey on diagnosis, treatment, and outcome of primary hyperoxaluria. Pediatr Nephrol. 2003;18(10):986-91.

30. Siva S, Barrack ER, Reddy GP, et al. A critical analysis of the role of gut Oxalobacter formigenes in oxalate stone disease. BJU Int. 2008;103(1):18-21.

31. Annuk M, Backman U, Holmgren K, Vessby B. Urinary calculi and jejunoileal bypass operation. A long-term follow-up. Scand J Urol Nephrol. 1998;32(3):177-80.

32. Schwille PO, Schmiedl A, Herrmann U, et al. Magnesium, citrate, magnesium citrate and magnesium-alkali citrate as modulators of calcium oxalate crystallization in urine: observations in patients with recurrent idiopathic calcium urolithiasis. Urol Res. 1999;27(2):117-26.

33. Bek-Jensen H, Fornander AM, Nilsson MA, Tiselius HG. Is citrate an inhibitor of calcium oxalate crystal growth in high concentrations of urine? Urol Res. 1996;24(2):67-71

34. Tiselius HG, Fornander AM, Nilsson MA. The effects of citrate and urine on calcium oxalate crystal aggregation. Urol Res. 1993;21 (5):363-6.

35. Lewandowski S, Rodgers AL. Idiopathic calcium oxalate urolithiasis: risk factors and conservative treatment. Clin Chim Acta. 2004; 345(1-2):17-34.

36. Lancina Martín JA, Rodríguez-Rivera García J, Novás Castro S, et al. Factores de riesgo metabólico en urolitiasis cálcica según el sexo y edad de los pacientes. Actas Urológicas Españolas. 2002;26(2):111-20. Available from: http://www.elsevier.es/en/node/2079359. Accessed in 2012 (Aug 16).

37. Grases F, Sanchis P, Perelló J, Costa-Bauzá A. Role of uric acid in different types of calcium oxalate renal calculi. Int J Urol. 2006;13(3):252-6.

38. Madore F, Stampfer MJ, Rimm EB, Curhan GC. Nephrolithiasis and risk of hypertension. Am J Hypertens. 1998;1 1(1 Pt 1):46-53.

39. Madore F, Stampfer MJ, Willet WC, Speizer FE, Curhan GC. Nephrolithiasis and risk of hypertension in women. Am J Kidney Dis. 1998;32(5):802-7.

40. Blackwood AM, Sagnella GA, Cook DG, Cappuccio FP. Urinary calcium excretion, sodium intake and blood pressure in a multi-ethnic population: results of the Wandsworth Heart and Stroke Study. J Hum Hypertens. 2001;15(4):229-37.

41. Cirillo M, Ciacci C, Laurénzi M, et al. Salt intake, urinary sodium, and hypercalciuria. Miner Electrolyte Metab. 1997;23(3-6):265-8.

42. Daudon M, Lacour B, Jungers P. Influence of body size on urinary stone composition in men and women. Urol Res. 2006;34(3):193-9.

43. Asplin JR, Coe FL. Hyperoxaluria in kidney stone formers treated with modern bariatric surgery. J Urol. 2007;177(2):565-9.

44. Zerwekh JE. Bone disease and idiopathic hypercalciuria. Semin Nephrol. 2008;28(2):133-42. 
45. Reed BY, GitomerWL Heller HJ, et al. Identification and characterization of a gene with base substitutions associated with the absorptive hypercalciuria phenotype and low spinal bone density. J Clin Endocrinol Metab. 2002;87(4):1476-85.

46. Gomes SA, dos Reis LM, Noronha IL, Jorgetti V, Heilberg IP. RANKL is a mediator of bone resorption in idiopathic hypercalciuria. Clin J Am Soc Nephrol. 2008;3(5):1446-52.

47. Sakhaee K, Maalouf NM, Kumar R, Pasch A, Moe OW. Nephrolithiasisassociated bone disease: pathogenesis and treatment options. Kidney Int. 2011;79(4):393-403.

48. Hall PM. Nephrolithiasis: treatment, causes, and prevention. Cleve Clin J Med. 2009;76(10):583-91.

49. Valle Díaz de la Guardia F, Arrabal Martín M, Arrabal Polo MA, et al. Litiasis renal en pacientes con hiperparatiroidismo primario. Evolución y tratamiento [Renal lithiasis in patients with primary hyperparathyroidism. Evolution and treatment]. Arch Esp Urol. 2010;63(1):32-40.

50. Arrabal Martín M, Valle Díaz de la Guardia F, Jiménez Pacheco A, et al. Tratamiento de la litiasis renal con bifosfonatos [The treatment of renal lithiasis with biphosphonates]. Arch Esp Urol. 2007;60(7):745-54.

51. Pak CY, Sakhaee K, Moe O, et al. Biochemical profile of stone-forming patients with diabetes mellitus. Urology. 2003;61(3):523-7.

52. Zimmerer T, Weiss C, Hammes HP, et al. Evaluation of urolithiasis: a link between stone formation and diabetes mellitus? Urol Int. 2009;82(3):350-5.

53. Tiselius HG; Advisory Board of European Urolithiasis Research and EAU Health Care Office Working Party for Lithiasis. Possibilities for preventing recurrent calcium stone formation: principles for the metabolic evaluation of patients with calcium stone disease. BJU Int. 2001;88(2):158-68.

54. Straub M, Hautmann RE. Developments in stone prevention. Curr Opin Urol. 2005;15(2):119-26.

55. Grases F, Costa-Bauza A, Prieto RM. Renal lithiasis and nutrition. Nutr J. 2006;5:23.

56. Fink HA, Akornor JW, Garimella PS, et al. Diet, fluid, or supplements for secondary prevention of nephrolithiasis: a systematic review and meta-analysis of randomized trials. Eur Urol. 2009;56(1):72-80.

57. Pietrow PR, Karellas ME. Medical management of common urinary calculi. Am Fam Physician. 2006;74(1):86-94.

58. Jiménez Verdejo A, Arrabal Martín M, Miján Ortiz JL, et al. Efecto del citrato potásico en la profilaxis de la litiasis urinaria [Effect of potassium citrate in the prophylaxis of urinary lithiasis]. Arch Esp Urol. 2001;54(9):1036-46.

59. Fernández-Rodríguez A, Arrabal-Martín M, García-Ruiz MJ, et al. Papel de las tiazidas en la profilaxis de la litiasis cálcica recidivante [The role of thiazides in the prophylaxis of recurrent calcium lithiasis]. Actas Urol Esp. 2006;30(3):305-9.

60. Arrabal-Martín M, Fernández-Rodríguez A, Arrabal-Polo MA, GarcíaRuiz MJ, Zuluaga-Gómez A. Extracorporeal renal lithotripsy: evolution of residual lithiasis treated with thiazides. Urology. 2006;68(5):956-9.
61. Arrabal-Polo MA, Arrabal-Martin M, Zuluaga-Gomez A. Alendronate and resorptive hypercalciuria [Alendronate and resorptive hypercalciuria]. Med Clin (Barc). 2011;137(7):333.

62. Bushinsky DA, Neumann KJ, Asplin J, Krieger NS. Alendronate decreases urine calcium and supersaturation in genetic hypercalciuric rats. Kidney Int. 1999;55(1):234-43.

63. Giusti A, Barone A, Pioli G, et al. Alendronate and indapamide alone or in combination in the management of hypercalciuria associated with osteoporosis: a randomized controlled trial of two drugs and three treatments. Nephrol Dial Transplant. 2009;24(5):1472-7.

\section{Sources of funding: None \\ Conflict of interest: None}

Date of first submission: January 5, 2012

Last received: May 12, 2012

Accepted: September 4, 2012

\section{Address for correspondence:}

Miguel Angel Arrabal-Polo

Rua Camino de Ronda, 143 4F.

Granada - Spain

Postal zip: 18003

E-mail: arrabalp@ono.com 